\title{
A SURVEY BASED STUDY ON IMPACT OF CLIMATE CHANGE ON CROPPING BY FARMERS IN NAGPUR DISTRICT
}

\author{
P A Lambat ${ }^{1}$, A P Lambat ${ }^{2}$ V S Dongre ${ }^{2}$ and $\mathrm{K}$ J Cherian ${ }^{3}$ \\ 1 Shri Mathuradas Mohota College of Science, Nagpur, M.S., India. \\ 2 Sevadal Mahila Mahavidyalaya \& Research Academy, Nagpur, M.S., India. \\ 3 D R B Sindhu Mahavidyalaya, Nagpur, M.S., India. \\ Corresponding Author lambatashish@gmail.com
}

\begin{abstract}
:
Much of the food we eat comes from crops which are affected by pests, diseases and extreme weather conditions. Studies have shown that diseases, insects and weeds interfere with $36.5 \%$ of crop production around the world. In total, $14.1 \%$ of crop losses are attributed to the occurrence of diseases, which represents an annual loss of $\$ 220$ billion dollars (Agrios, 2005). The data pertaining to the impact of climate change on the agricultural practices of the inhabitants of the study area was assessed using a scientific approach. Prior to actual data collection, a reconnaissance survey of the study area was conducted. In view of the study results, it is concluded that there is noticeable change in damages caused by diseases to crop yield, crop yield has gone down noticeably as a function of climatic changes.
\end{abstract}

Keywords: Reconnaissance survey, crop yield, Primary Data Collection and Interview Schedule Development.

\section{INTRODUCTION:}

Much of the food we eat comes from crops which are affected by pests, diseases and extreme weather conditions. Studies have shown that diseases, insects and weeds interfere with $36.5 \%$ of crop production around the world. In total, $14.1 \%$ of crop losses are attributed to the occurrence of diseases, which represents an annual loss of $\$ 220$ billion dollars (Agrios, 2005). In addition to monetary losses, crop destruction causes malnutrition and hunger. To reduce the effects of plant diseases, millions of kilograms of pesticides are used to treat seed, soil and harvested fruits every year, which increases production costs and environmental pollution.

The environment may affect the availability, growth stage, succulence and genetic susceptibility to diseases of plants (Agrios, 2005). Therefore, agricultural production is extremely susceptible to climate change. According to the IPCC, (2007), climate change will reduce yields in the $21^{\text {st }}$ century. However, the effects of climate change will be highly variable and dependent on the region. Climate change will affect temperature, precipitation, $\mathrm{CO}_{2}$ levels and frequency of extreme weather events, so these will have a significant effect on agricultural production and the temporal and spatial distribution of pests and diseases (Peng et. al., 2004; Rosenzweig and Tubiello, 2007; Ghini et. al. 2008) Yields will increase due to a sharp rise in the concentration of $\mathrm{CO}_{2}$ and productivity will be limited by other nutrients or climatic events such as drought or floods (Amthor, 2001). According to the IPCC, (2007), crop productivity at mid to high latitudes (areas from $35^{\circ}$ to $90^{\circ}$ ) will increase slightly as the average temperature increases by 1 to $3^{\circ} \mathrm{C}$, depending on the crop type. Alternatively at lower latitudes, especially seasonally dry and tropical regions, crop productivity is projected to decrease for even small local temperature increases $\left(1-2^{\circ} \mathrm{C}\right)$, because increases in the frequency of droughts and floods will affect local crop production negatively, which would increase risk of hunger (IPCC, 2007).

The direct effects of elevated ozone and carbon dioxide on spring wheat infected with Puccinia recondite. Crop yield and growth were measured for plants exposed to two levels each of carbon dioxide and ozone and either inoculated with rust or left uninoculated. Results showed that ozone damage to leaves is largely dependent on both carbon dioxide concentrations as well as disease. Additionally, elevated carbon dioxide levels appeared to reduce and delay leaf damage caused by ozone (Tiedemann and Firsching, 2000).

\section{MATERIAL AND METHODS:}

The data pertaining to the impact of climate change on the agricultural practices of the inhabitants of the study area was assessed using a scientific approach. Prior to actual data 
collection, a reconnaissance survey of the study area was conducted. Based on the first hand information obtained from this survey and the relevant secondary data, a research instrument (interview schedule) was developed for data generation.

\section{Primary Data Collection}

The primary data was collected by using a reliable and valid research instrument. The process of developing the research instrument for this study was based on generally accepted principles of instrument design, and was carried out according to the standard methodology. Data was collected from July 2010 to December 2014 from Meteorology Department at Nagpur Airport, Nagpur and Agriculture Statistics Department, Government of Maharashtra, Nagpur. Care was taken to ensure the accuracy and reliability of data collection procedure. This involved the activities described below.

\section{Interview Schedule Development}

Interview schedules are typically used for feedback research to determine the current status or "situation," or to estimate the distribution of characteristics in a population. Developing an interview schedule is one of the most critical stages in the survey process. Care was taken so that

- Each question should relate directly to the study objectives

- Every respondent should be able to answer every question (unless instructed otherwise).

- Each question was phrased in such a way so that all respondents interpret it the same way.

- Each question was framed in such a way that it should provide answers to what is needed to be known and not what would be nice to know.

\section{Main parts of a interview schedule Invitation}

Invitation involved identifying how the respondents would be invited i.e mainly through group discussions at choupal of village with villagers and identification, selection of cultivars was done to answer the survey interview schedule. Personal interaction was used as a means to collect data from the people living in respective villages and cultivating atleast $2-3$ study crops in the study region since atleast past 10yrs. The research objectives were clearly communicated to the respondents prior to data collection. There were five main parts of an invitation:

- Introduction of the topic

- Why the respondents have been selected to respond
- How long will the interview take

- What benefit will they get for responding

- How their responses will be used (confidentiality)

Based on the objectives, questions/statements were framed such that each statement would yield single response

\section{Selection of Measurement Scales}

In the present study, Fixed Response (Qualitative) Rating scale was used. This type of scale was selected as fixed response questions are quick to answer, which also facilitate analyzing the results.

\section{Pilot Study}

A pilot study was conducted to estimate the reliability and validity of the research instrument. This exercise was carried out to validate and improve the research instrument in terms of its format and layout, the wording of statements and also the overall content of items.

\section{Reliability Estimation}

Reliability is a measure of how consistent the results of using a survey questionnaire will be. By consistent we mean that respondents understand the true meaning of the question as it is stated. Reliability was determined using a "pilot test" with the proposed interview schedule. Reliability of the instrument was assessed using the test-retest method, which allowed determining the repeatability of the instrument. The criterion suggested by Nunnally (1978) i.e. a coefficient value larger than 0.6 (which demonstrates the internal consistency) was used. The test-retest method results indicated that the lowest coefficient was 0.780 , which is higher than the cut off value; hence, on the basis of this result, it was evident that the developed instrument was reliable and hence, it was used for data collection.

\section{Validity determination}

The validity of a measure refers to the extent to which it measures what it was intended to measure. Three different types of validity were determined:

- Content validity: The contents of the instrument were selected on the basis of comprehensive literature survey, where care was taken to use literature published in the authentic journals, magazines, periodicals and Govt. reports.

- Construct validity: Construct validity of the research instrument was also determined prior to its use for data collection. A measure has construct validity if it measures the theoretical construct or trait that it was designed to measure.

- Criterion-related validity: The criterionrelated validity of the instrument was 
evaluated by examining the correlation coefficients obtained for the selected variables of the instrument.

\section{Sample Size}

It is important to know the nature of the sampling frame. A study that is based completely on a sample drawn from limited area cannot be used to generalize about the complete population. In view of this a sample size of 400 was considered as an appropriate sample size for present study. The selection of samples was carried out randomly to minimize the bias.

\section{Data collection}

The data collection in view of the objectives of the study involved visit to various localities and interaction with the concerned person. Each day of data collection involved the following activities:

\begin{tabular}{|c|c|}
\hline When? & What? \\
\hline $\begin{array}{l}\text { Before } \\
\text { going out } \\
\text { to collect } \\
\text { data }\end{array}$ & $\begin{array}{l}\text { - Checked that data collection of } \\
\text { all the material necessary for } \\
\text { field visits and confirm } \\
\text { transport arrangement each } \\
\text { day. } \\
\text { - Called concerned } \\
\text { representative of the locality to } \\
\text { be visited and confirmed } \\
\text { appointment. }\end{array}$ \\
\hline $\begin{array}{lr}\text { On } & \text { arrival } \\
\text { at } & \text { the } \\
\text { study area }\end{array}$ & $\begin{array}{l}\text { - Introduced purpose of survey } \\
\text { and reminded to the people of } \\
\text { the visit's purpose. } \\
\text { - Distribution of Data } \\
\text { Collection Form to identified } \\
\text { Farmers. } \\
\text { - Verified and completed the } \\
\text { outlet information on first } \\
\text { page of the data sheet } \\
\text { Generated necessary data } \\
\text { from interaction with the } \\
\text { people. } \\
\text { Checked whether all data } \\
\text { entered into the data } \\
\text { collection form before leaving } \\
\text { the locality. }\end{array}$ \\
\hline
\end{tabular}

\section{RESULTS AND DISCUSSION:}

Important Factors for Crop Disease Management Table 01: Changes in farming techniques during the last decade

\begin{tabular}{|c|c|c|c|}
\hline Change & $\begin{array}{l}\text { Number of } \\
\text { Respondents }\end{array}$ & Percentage & $\begin{array}{l}\text { Chi- } \\
\text { Square } \\
\text { Test }\end{array}$ \\
\hline $\begin{array}{l}\text { To a large } \\
\text { extent }\end{array}$ & 189 & 47.3 & \multirow{3}{*}{$\begin{array}{l}\mathbf{x}^{\mathbf{2}}= \\
59.456 \\
<\mathbf{0 . 0 5}\end{array}$} \\
\hline $\begin{array}{l}\text { To a small } \\
\text { extent }\end{array}$ & 146 & 36.5 & \\
\hline Not at all & 65 & 16.3 & \\
\hline
\end{tabular}

\begin{tabular}{|l|l|l|l|}
\hline Total & 400 & 100.0 & \\
\hline
\end{tabular}

Table 01 presents results regarding the average changes in farming techniques prevailing in the study area during the last few decades. Majority of the respondents $(47.3 \%)$ confirmed that the change in farming techniques was to a large extent. Whereas $36.5 \%$ respondents confirmed that there was change in the farming techniques to a small extent and $16.3 \%$ respondents replied that there was no change in the farming techniques in the last decade. There was significant difference $(p<0.05)$ in the change in farming techniques during different decades (Fig. 01). Thus, on the basis of the study results, it is concluded that there is noticeable change in the farming techniques during the last few decades.

Pathogens show both positive and negative responses to air pollutants. A study is described in which these opposite responses in two different fungal species were observed in a field $\mathrm{SO}_{2}$-fumigation system and confirmed in controlled laboratory fumigations. Models are presented to describe the complex pathways by which air pollutants could influence host plant performance via impacts on pests and pathogens (Bell, 1993).

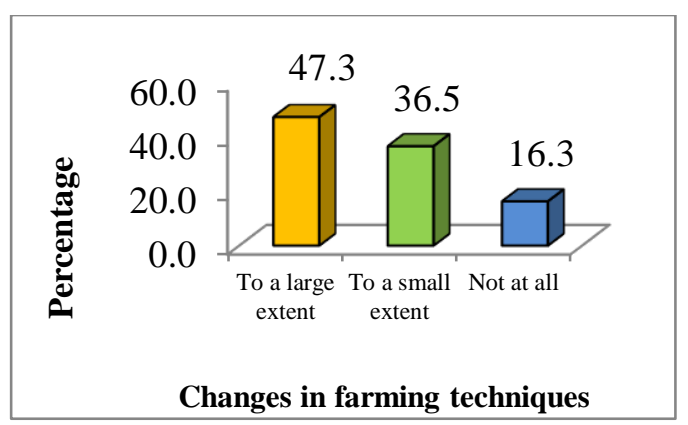

Fig. 01 : Change in farming techniques in different decades.

Changes in vector population control process Table 02: Changes in vector population control process

\begin{tabular}{|c|c|c|c|}
\hline Change & $\begin{array}{l}\text { Number of } \\
\text { Respondents }\end{array}$ & Percentage & $\begin{array}{l}\text { Chi- } \\
\text { Square } \\
\text { Test }\end{array}$ \\
\hline $\begin{array}{l}\text { To a large } \\
\text { extent }\end{array}$ & 287 & 71.8 & \multirow{4}{*}{$\begin{array}{l}\mathbf{x}^{2}= \\
272.58 \\
<\mathbf{0 . 0 5}\end{array}$} \\
\hline $\begin{array}{l}\text { To a small } \\
\text { extent }\end{array}$ & 78 & 19.5 & \\
\hline Not at all & 35 & 8.8 & \\
\hline Total & 400 & 100.0 & \\
\hline
\end{tabular}

Table 2: The changes in vector population control process prevailing in the study area during the last few decades were presentated in 
Table 02. Majority of the respondents (71.8\%) confirmed that the change in vector population control process was to a large extent. Whereas, $19.5 \%$ respondents confirmed that there was change in vector population control process to a small extent and $8.8 \%$ respondents replied that there was no change in vector population control process in the last decade. There was significant difference $(p<0.05)$ in the change in vector population control process in different decades (Fig. 02). Thus, on the basis of the study results suggested that there is noticeable change in vector population control process during the last few decades.

Harvell et al. (2002) demonstrated that warm winters with high night temperatures facilitate the survival of pathogens, accelerate life cycles of vectors and fungi, and increase sporulation and aerial fungal infection. Moreover, the results of the aforementioned study suggested that the number of pathogens moving northward will increase as increasing temperature makes that previously inclement areas are more conducive. Matros et. al., (2006). The titre of viral coat-protein was markedly reduced in leaves under these conditions at both nitrogen levels. The accumulation of phenylpropanoids may result in an earlier confinement of the virus at high $\mathrm{CO}_{2}$.

\begin{tabular}{|cccc|}
\hline & 80.0 \\
40.0
\end{tabular}

Fig. 02 : The change in vector population control process in different decades. Changes in use of pesticides Table 03: Changes in use of pesticides

\begin{tabular}{|c|c|c|c|}
\hline Change & $\begin{array}{l}\text { Number of } \\
\text { Respondents }\end{array}$ & Percentage & $\begin{array}{l}\text { Chi- } \\
\text { Square } \\
\text { Test }\end{array}$ \\
\hline $\begin{array}{l}\text { To a } \\
\text { large } \\
\text { extent }\end{array}$ & 334 & 83.5 & \multirow{4}{*}{$\begin{array}{l}\mathbf{x}^{2}= \\
453.06 \\
<\mathbf{0 . 0 5}\end{array}$} \\
\hline $\begin{array}{l}\text { To a } \\
\text { small } \\
\text { extent }\end{array}$ & 35 & 8.8 & \\
\hline $\begin{array}{l}\text { Not at } \\
\text { all }\end{array}$ & 31 & 7.8 & \\
\hline Total & 400 & 100.0 & \\
\hline
\end{tabular}

Table 03 represents results regarding the changes in use of pesticides prevailing in the study area during the last few decades. Majority of the respondents $(83.5 \%)$ confirmed that the change in use of pesticides was to a large extent. Whereas $8.8 \%$ respondents confirmed that there was change in use of pesticides to a small extent and $7.8 \%$ respondents replied that there was no change in use of pesticides in the last decade. There was significant difference $(p<0.05)$ in the change in use of pesticides during different decades (Fig. 3). Thus, on the basis of the study results, it is concluded that there is noticeable change in use of pesticides during the last few decades.

Climate change is likely to alter the balance between insect pests, their natural enemies and their hosts. One of the most important effects of climate change will be to alter the synchrony between host and insect pest development, particularly in spring, but also in autumn. The predicted rise in temperature will also generally favor insect development and winter survival, although there will be some exceptions. Most studies have concluded that insect pests will generally become more abundant as temperatures increase, through a number of inter-related processes, including range extensions and phenological changes, as well as increased rates of population development,

growth, and migration and over-wintering, which will trigger the use and misuse of Pesticides in agro-ecosystems (Palikhe, 2007).

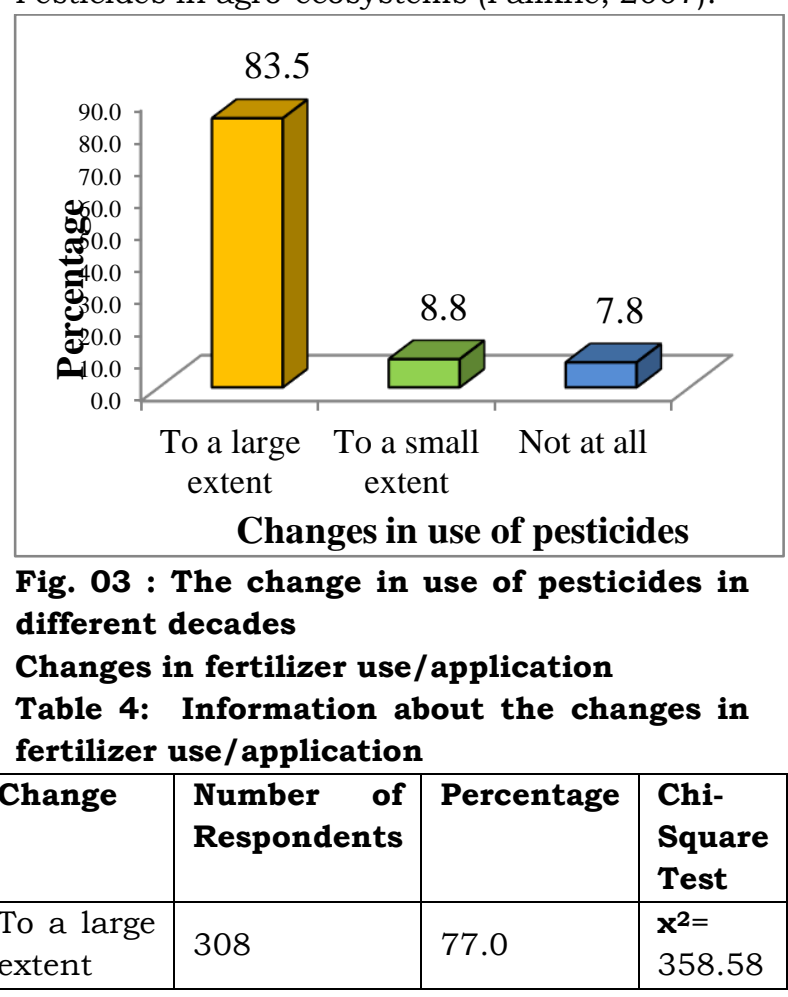




\begin{tabular}{|l|l|l|l|}
\hline $\begin{array}{l}\text { To a small } \\
\text { extent }\end{array}$ & 78 & 19.5 & $<0.05$ \\
\cline { 1 - 3 } Not at all & 14 & 3.5 & \\
\hline Total & 400 & $\mathbf{1 0 0 . 0}$ & \\
\hline
\end{tabular}

Table 4: The changes in fertilizer use/application prevailing in the study area during the last few decades is presentated in Table 6.9. Majority of the respondents $(77.0 \%)$ indicated that the change in fertilizer use/application was to a large extent. Whereas (19.5\%) respondents indicated that there was change in use of fertilizer use/application to a small extent and further 3.5\% farmers indicated that there was no change in use of fertilizer use/application in the last decade. There was significant difference $(\mathrm{p}<0.05)$ in the change in use of fertilizer use/application in different decades (Fig. 6.9). Thus, on the basis of the study results which indicate that there is noticeable change in fertilizer use/application during the last few decades.

Global warming is also related to increased concentrations of greenhouse gases, such as $\mathrm{CO} 2$, that will affect crop pests indirectly through changes in plants and vegetation composition, quantity and quality. Studies have been conducted on the impact of increased $\mathrm{CO} 2$ and $\mathrm{O} 2$ concentration levels (free-air gas concentration enrichment - FACE) to the level estimated for predictions for the mid-twenty-first century, demonstrating higher insect pressure (of Japanese beetle, potato leafhopper, western corn rootworm, Mexican bean beetle) requiring additional insecticide usage (Hamilton et. al., 2005).

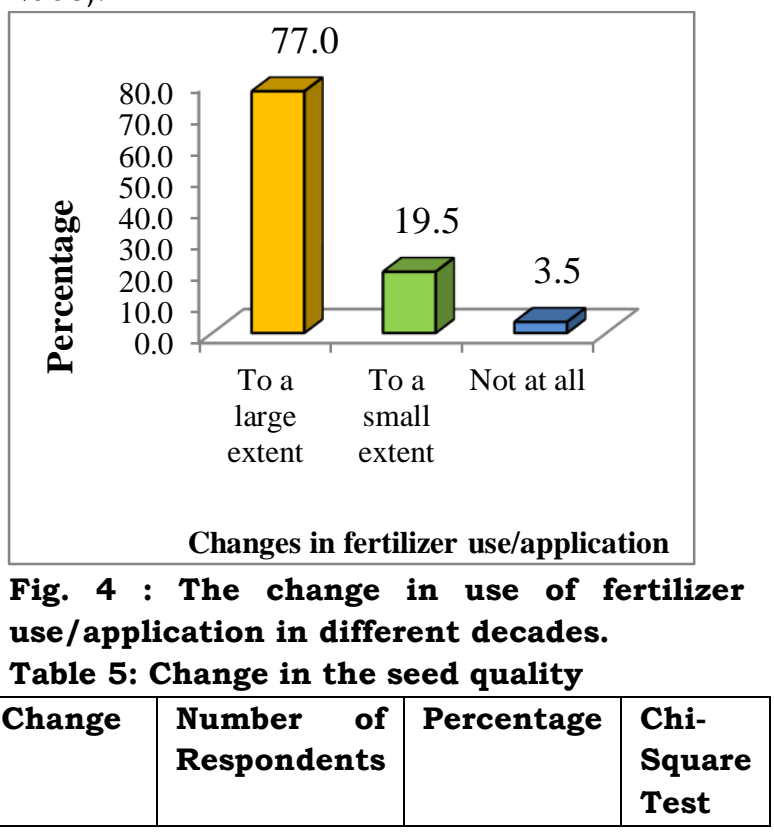

\begin{tabular}{|l|l|l|l|}
\hline $\begin{array}{l}\text { To a } \\
\text { large } \\
\text { extent }\end{array}$ & 212 & 53.0 & \\
\cline { 1 - 2 } & 118 & 29.5 & $\mathbf{x}^{\mathbf{2}=}$ \\
$\begin{array}{l}\text { To } \\
\text { small } \\
\text { extent }\end{array}$ & & $\mathbf{0 . 0 5}$ \\
\cline { 1 - 2 } Not at all & 70 & 17.5 & \\
\hline Total & 400 & 100.0 & \\
\hline
\end{tabular}

The changes in seed quality prevailing in the study area during the last few decades were given in Table 5. Majority of the respondents $(53 \%)$ confirmed that the change in seed quality was to a large extent. Whereas, 29.5\% respondents confirmed that there was change in seed quality to a small extent and $17.5 \%$ respondents replied that there was no change in seed quality in the last decade. There was significant difference $(p<0.05)$ in the change in seed quality in different decades (Fig. 5). Thus, on the basis of the study results, it is concluded that there is noticeable change in seed quality during the last few decades. On the basis of the study results, it is concluded that in view of the climatic changes, farming techniques, vector population control process, use of pesticides, fertilizers and seed quality have seen major changes. Seed germination in response to elevated $\mathrm{CO}_{2}$ has been reported to decrease (Farnsworth and Bazazz, 1995; Andalo et. al., 1996; Quaderi and Reid, 2005), show no change (Thomas et. al., 2009; Way et. al., 2010) or increase (Edwards et. al., 2001). The responses vary among species (Ziska and Bunce, 1993) and genotypic variation has also been reported (Andalo et. al., 1996).

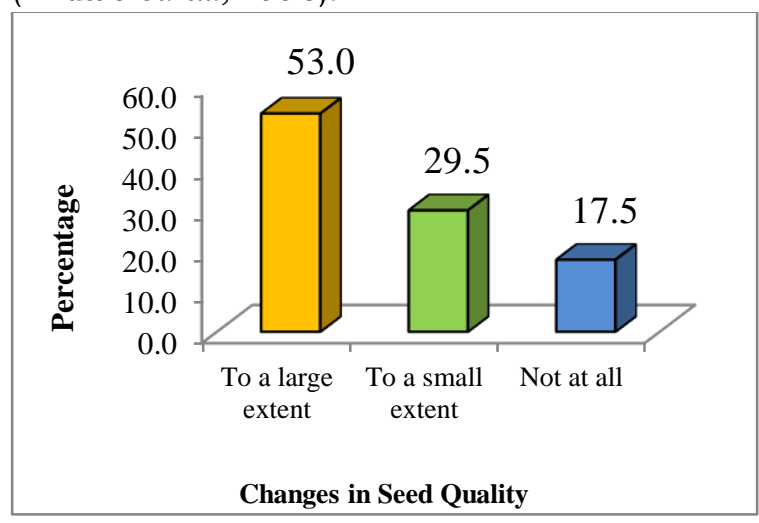

Fig. 5 : The change in seed quality in different decades.

Table 6: Information about the damages caused by diseases to crop yield in the study area

\begin{tabular}{|l|l|l|l|}
\hline Crop yield & \multicolumn{2}{|c|}{ Chi- } \\
\cline { 2 - 3 } & Cotton & Tur & $\begin{array}{l}\text { Square } \\
\text { Test } \\
\text { Results }\end{array}$ \\
\hline
\end{tabular}




\begin{tabular}{|c|c|c|c|}
\hline No Change & 312 & 144 & \multirow{4}{*}{$\begin{array}{l}x^{2}=91.003 \\
P<0.05\end{array}$} \\
\hline $\begin{array}{l}\text { To a small } \\
\text { extent }(<10 \%)\end{array}$ & 08 & 40 & \\
\hline $\begin{array}{l}\text { To a } \\
\text { moderate } \\
\text { extent (10 to } \\
30 \%)\end{array}$ & 18 & 31 & \\
\hline $\begin{array}{l}\text { To a large } \\
\text { extent (>30\%) }\end{array}$ & 62 & 92 & \\
\hline Total & 400 & 400 & \\
\hline
\end{tabular}

The extent of damage caused by various diseases to crop yield during the last few decades were presented in Table 6. It was observed from the questionnaire that the damages caused to crop yield in the study area were to a large extent to the crops of Tur (92), Whereas the damages caused to crop yield to moderate extent were Cotton (18) Tur (31), Whereas the damages caused by diseases to crop yield to a small extent were Cotton (08), Tur (40). Thus, on the basis of the study results, it is concluded that there is noticeable change in damages caused by diseases to crop yield during the last few decades In view of the obtained data, it is concluded that the crop yield has gone down noticeably as a function of climatic changes.

\section{CONCLUSION:}

On the basis of the study results, it is concluded that in view of the climatic changes, farming techniques, vector population control process, use of pesticides, fertilizers and seed quality have seen major changes. In view of the study results, it is concluded that there is noticeable change in damages caused by diseases to crop yield, crop yield has gone down noticeably as a function of climatic changes.

\section{ACKNOLEDGMENT:}

Researchers are thankful to Dr. K D Thakur, HOD, Plant Pathology for his generous help to conduct experiment in Field of Dr.P D K V's College of Agriculture, Nagpur, M.S., India.

\section{REFERENCE:}

Agrios G.N., (2005), Plant Pathology. 5th Ed. Elsevier, USA, 922.

IPCC. (2007), Climate change: the physical science basis. Geneva: IPCC, 996. (Assessment Report, 4).

Shaobing Peng Jianliang Huang John E. Sheehy, Rebecca C. Laza, Romeo M. Visperas, Xuhua Zhong, Grace S. Centeno, Gurdev S. Khush and Kenneth G. Cassman (2004), Rice yields decline with higher night temperature from global warming, The Proceedings of National
Academy of Science, 101 (27): 99719975.

Cynthia Rosenzweig, Francesco and Nicola Tubiello (2007), Adaptation and mitigation strategies in agriculture: an analysis of potential synergies, Mitigation and Adaptation Strategies for Global Change, 12, (5): 855-87.

Ghini, R.; Hamada, E.; Pedro Júnior, M.J.; Marengo, J.A. and Gonçalves, R.R.V. (2008), Risk analysis of climate change on coffee nematodes and leaf miner in Brazil. Pesquisa Agropecuária Brasileira, 43: 187-194.

Amthor, J.S., (2001), Effects of atmospheric CO2 concentration on wheat yield: review of results from experiments using various approaches to control $\mathrm{CO} 2$ concentration. Field Crops Res. 73: 1-34.

IPCC. (2007), Climate change: the physical science basis. Geneva: IPCC, 996. (Assessment Report, 4)

IPCC. (2007), Climate change: the physical science basis. Geneva: IPCC, 996. (Assessment Report, 4)

A.V Tiedemann, K.H Firsching (2000), Interactive effects of elevated ozone and carbon dioxide on growth and yield of leaf rustinfected versus non-infected wheat, Environmental Pollution, 108(3): 357363.

J.N.B. Bell1, S. McNeill, G. Houlden, V. C. Brown and P. J. Mansfield, (1993), Atmospheric change: effect on plant pests and diseases, Parasitology, 106( S1) : S11$\mathrm{S} 24$.

Harvell H.C, Mitchell CE, Ward J.R, Altizer S, Dobson A.P, Ostfeld RS, and Samuel M.D (2002), Climate warming and disease risks for terrestrial and marine biota. Science, 296: 2158-2162.

Matros A, Amme S, Kettig B, Buck-Sorlin GH, Sonnewald U, Mock HP (2006). Growth at elevated $\mathrm{CO} 2$ concentrations leads to modified profiles of secondary metabolites in tobacco cv. SamsunNN and to increased resistance against infection with potato virus Y. Plant Cell Environ. 29: $126-137$.

Palikhe, B. R., (2007), Relationship Between Pesticide Use And Climate Change For Crops, Pesticide Registration and Management Office, Plant Protection Directorate of Department of Agriculture, 83-91.

Hamilton, J.C., Dermody, O., Aldea, M., Zangerl, A.R., Rogers, A., Berembaum, M.R. \& De Lucia, E.H. (2005), Anthropogenic 
changes in tropospheric composition increase susceptibility of soybean to insect herbivory. Environmental Entomology, 34(2): 479-485.

Farnsworth, E. J. \& Bazazz, F. A. (1995), Interand intrageneric differences in growth, reproduction, and fitness of nine herbaceous annual species grown in elevated $\mathrm{CO}_{2}$ environments. Oecologia, 104: 454-466.

Andalo, C., Godelle, B., Lefranc, M., Mousseau, M. \& Tillbottraud, I. (1996), Elevated $\mathrm{CO}_{2}$ decreases seed germination in Arabidopsis thaliana. Global Change Biology, 2: 129-135.

Quaderi, M.M. \& Reid, D.M. (2005), Growth and physiological responses of canola (Brassica napus) to UV-B and $\mathrm{CO}_{2}$ under controlled environment conditions. Physiologia Plantarum, 125:247-259.
Thomas, J.M. G., Prasad, P. V. V., Boote, K. J. \& Allen, L.H. (2009), Seed composition, seedling emergence and early seedling vigour of red kidney bean seed produced at elevated temperature and carbon dioxide. Journal of Agronomy and Crop Science, 195: 148-156.

Way, D. A., Ladeau, S. L., Mccarthy, H. R., Clark, J. S., Oren, R., Finzi, A.C. \& Jackson, R. B. (2010), Greater seed production in elevated $\mathrm{CO}_{2}$ is not accompanied by reduced seed quality in Pinus taeda L. Global Change Biology, 16:1046-1056.

Ziska, L.H. \& Bunce, J. A. (1993). The influence of elevated $\mathrm{CO} 2$ and temperature on seed ermination and emergence from soil. Field Crops Research ,34:147-157. 